\title{
Molar intrusion with orthodontic mini-implants: case reports
}

\author{
Intrusão de molares com mini-implantes ortodônticos: relato de casos
}

Carollyne Mota TIAGO'

Luis PREVIDENTE ${ }^{1}$

Paulo Roberto Aranha NOUER²

\begin{abstract}
Intraoral skeletal anchorage may be obtained by means of mini-implants that allow simpler and more effective orthodontic biomechanics. These devices have become increasingly popular, particularly because their use requires little cooperation from the patient. Three clinical cases were presented, in which the efficiency of mini-implants for maxillary and mandibular molar intrusion was demonstrated. In all treatments, the authors sought to insert the mini-implants in the vestibular and lingual regions to obtain better torque control of the tooth, thereby avoiding undesirable momentum, rotation and tipping. Therefore, the intrusive forces with a force intensity ranging between $150 \mathrm{~g}$ and $200 \mathrm{~g}$, were obtained by means of chain elastics, always passing through the center of resistance of the molars to be moved. In the cases treated, there was intrusion with over-correction in a mean period of six, and maximum of seven months, thus allowing better rehabilitation of the patient submitted to previous orthodontic treatment, and after conclusion of this phase, good stability of the mechanics used.
\end{abstract}

Indexing terms: Dental implantation. Orthodontics. Tooth movement.

\section{RESUMO}

A ancoragem esquelética intrabucal pode ser obtida por meio de mini-implantes, que permite uma biomecânica ortodôntica mais simples e efetiva, e tem se tornado cada vez mais popular, principalmente por necessitar de pouca colaboração do paciente. Foram apresentados três casos clínicos, nos quais os mini-implantes demonstraram sua eficácia na intrusão de molares superiores e inferiores. Buscou-se, em todos os tratamentos, a instalação dos mini-implantes por vestibular e por lingual, a fim de se obter melhor controle de torque do dente, evitando momentos, rotações e inclinações indesejáveis. Para tanto as forças intrusivas, com intensidade de força variando entre $150 \mathrm{~g}$ e $200 \mathrm{~g}$, foram obtidas por meio de cadeias elásticas, sempre passando sobre o centro de resistência dos molares a serem movimentados. Nos casos tratados, em um período médio de seis meses e máximo de sete meses, houve intrusão com sobrecorreção, permitindo assim melhor reabilitação do paciente submetido a tratamento ortodôntico prévio e, após a finalização dessa fase, boa estabilidade da mecânica empregada.

Termos de indexação: Implante dentário. Ortodontia. Movimentação dentária.

\section{INTRODUCTION}

Early loss of mandibular permanent first molars is a clinical problem that routinely occurs, and results in extrusion of the maxillary first molar, and even of the maxillary second molar ${ }^{1}$. Less frequently, the extrusion of the mandibular first and or second molar also occurs, due to loss of the maxillary molars.

Associated with extrusion, there are common problems such as periodontal pockets, premature contacts in centric relation, occlusal interferences in the lateralprotrusion movements and lack of prosthetic space, making it difficult to rehabilitate the stomatognathic system ${ }^{1-2}$.
Among the proposals found in the literature for correcting molar extrusion, molar intrusion by means of alignment and leveling has been described, however, with limited results'; the extraoral arch, which depends completely on the patient's cooperation ${ }^{4}$; bite blocks activated by springs are another type of appliance indicated, however with low frequency of success ${ }^{4}$; an intrusion arch may also be an option ${ }^{5}$, however this appliance works only in patients in the growth stage; a removable molar intrusion appliance ${ }^{3}$ resulting in a mean intrusion of 3.0 $\mathrm{mm}$ in three months may be efficient, provided that the patient cooperates; crown wear followed by endodontic treatment and periodontal surgery ${ }^{1}$ - a high cost treatment

\footnotetext{
${ }^{1}$ Faculdade de Ciências do Tocantins, Curso de Odontologia, Departamento de Ortodontia. Av. José de Brito, 730, Santa Anhanguera, Araguaína - TO Correspondência para / Correspondence to: CM TIAGO E-mail: <caroll_mota@yahoo.com.br>.

${ }^{2}$ Faculdade São Leopoldo Mandic, Programa de Pós-Graduação em Odontologia - Área de concentração em Ortodontia. Campinas, SP, Brasil.
} 
and completely compromises the vitality of the tooth ${ }^{2}$; or the surgical impaction of extruded teeth, involving an aggressive and uncomfortable operation for the patient ${ }^{1,2}$.

Because the intra and extraoral anchorage systems have presented little acceptance by patients, an intraoral skeletal anchorage system was developed, by means of mini-implants. The literature has demonstrated the efficiency of this system for the intrusion of molars, as it allows the use of simpler and more effective orthodontic mechanics ${ }^{2,6}$. In addition to being low cost, it makes immediate orthodontic loading possible ${ }^{7}$, without the need for a period of waiting for bone healing ${ }^{8}$.

Therefore, the aim of this article was to present three clinical cases, emphasizing the versatility of orthodontic mini-implants in the biomechanics of molar intrusion.

\section{CASE REPORTS}

\section{Clinical case 1}

The patient, a 51-year-old man, presented absence of the mandibular molars and extrusion of the maxillary molars and maxillary right second premolar (Figures 1A, 1B). For oral rehabilitation with osseointegrated implants, intrusion and verticalization of the maxillary molars was requested. For intrusion and verticalization on the right side, two mini-implants were inserted, in the vestibular and palatine region between the second and first molar. As activation mode, chain elastics were connected to a loop-band system. For intrusion of the maxillary left second molar, two mini-implants were inserted in the region of the premolars, and a palatine bar with 0.8 wire was fixed with resin composite to the head of the mini-implants, taking into consideration the vectors of force planned (Figures 1C, 1D, 1E). The active period of treatment was seven months, and soon afterwards the patient began with oral rehabilitation (Figures 1F, G, $\mathrm{H}$, I, J, K).

\section{Clinical case 2}

The patient, a 42-year-old woman presented absence of teeth 36 and 37, extensive extrusion of tooth 26 (Figure 2A). For placement of an osseointegrated implant, intrusion of tooth 26 was requested. During evaluation of the periapical radiographs, a small amount of space for mini-implant insertion found between the roots. To resolve this, prior orthodontic movement was performed for the purpose of promoting space between the vestibular roots of teeth 26 and 27 (Figures $2 B$ and 2C). Having obtained the spaces, two mini-implants were installed: one in the palatine alveolar process in the interdental space between teeth 26 and 25; and the other in the vestibular process of the maxilla in the interdental space between teeth 26 and 27 (Figures 2D and 2E). With the aid of chain elastics, intrusion occurred in six months (Figure 2F).

\section{Clinical case 3}

The patient, a 26-year-old woman, presented loss of maxillary molars and extrusion of tooth 47 (Figure $3 \mathrm{~A}$ ). With the purpose of orthodontic preparation for oral rehabilitation, intrusion of tooth 47 was proposed. To achieve this, a mini-implant was used for the edentulous areas; this unit measured $2.0 \mathrm{~mm}$ in diameter and $10 \mathrm{~mm}$ long, and had a device for cementation, designed by the abutment manufacturer. By means of impression transfer and obtaining a working model, an orthodontic device was constructed, taking into consideration the vectors of orthodontic forces required for performing intrusion and verticalization of the above-mentioned molar (Figures $3 \mathrm{C}$ and 3D). After the device was inserted it was activated by changing the exchanging the chain elastic from the vestibular and lingual regions (Figures $3 \mathrm{E}$ and $3 \mathrm{~F}$ ). In the period of six months intrusion with over-correction was obtained (Figure 3G).

\section{DISCUSSION}

For molar intrusion, mini-implants with orifices and grooves in the head were selected, that allowed elastic or metal ligatures, or springs to be inserted, without the need for complete fixed appliances ${ }^{7}$, and that respected the keratinized mucosa limit ${ }^{8,10}$. Eventually, if it were necessary to insert an appliance in the region of the non-keratinized alveolar mucosa, an alternative would be to insert a submersed mini-implant with a tie wire, providing a link with the external medium, to make it possible to perform the desired activation ${ }^{9-11}$.

In all treatments, the authors sought to insert the mini-implants in the vestibular and lingual regions to obtain better torque control of the tooth, thereby avoiding

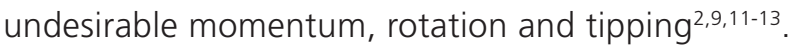

The mini-implant sizes were chosen according to the space available between the tooth roots and nearby anatomic structures, and the depth of penetration into bone tissue of a minimum of 5 to $6 \mathrm{~mm}^{11,14}$. 

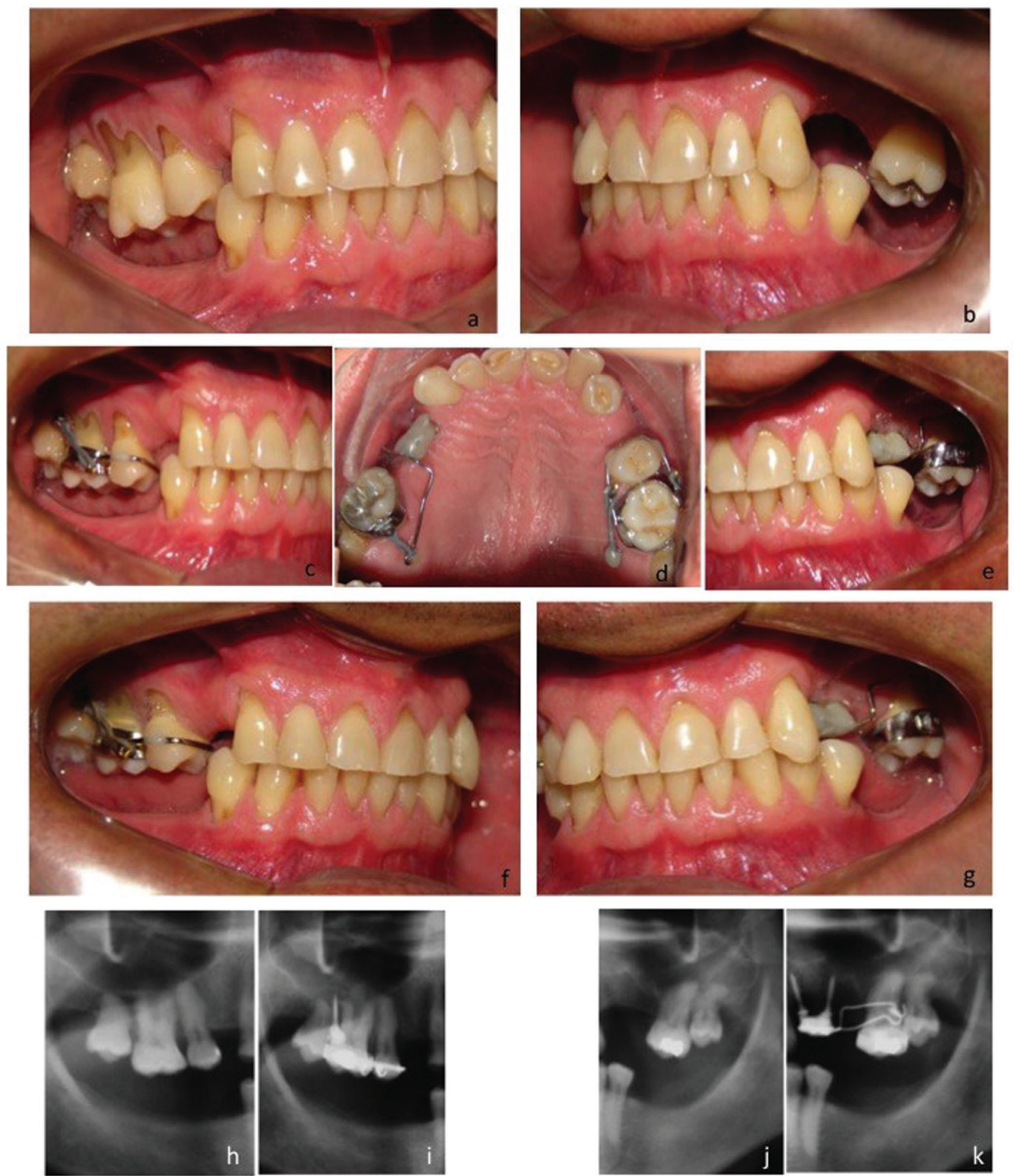

Figure 1. A, B - Absence of mandibular molars, extrusion and mesial tipping of maxillary teeth; Right and left side views; C - D - and: Vestibular and palatine mini-implants for intrusion. Right side view and and left occlusal and side views. F - G, Clinical aspect after intrusion; H - K, Radiographs comparing the initial aspects with those after othodontic movement 

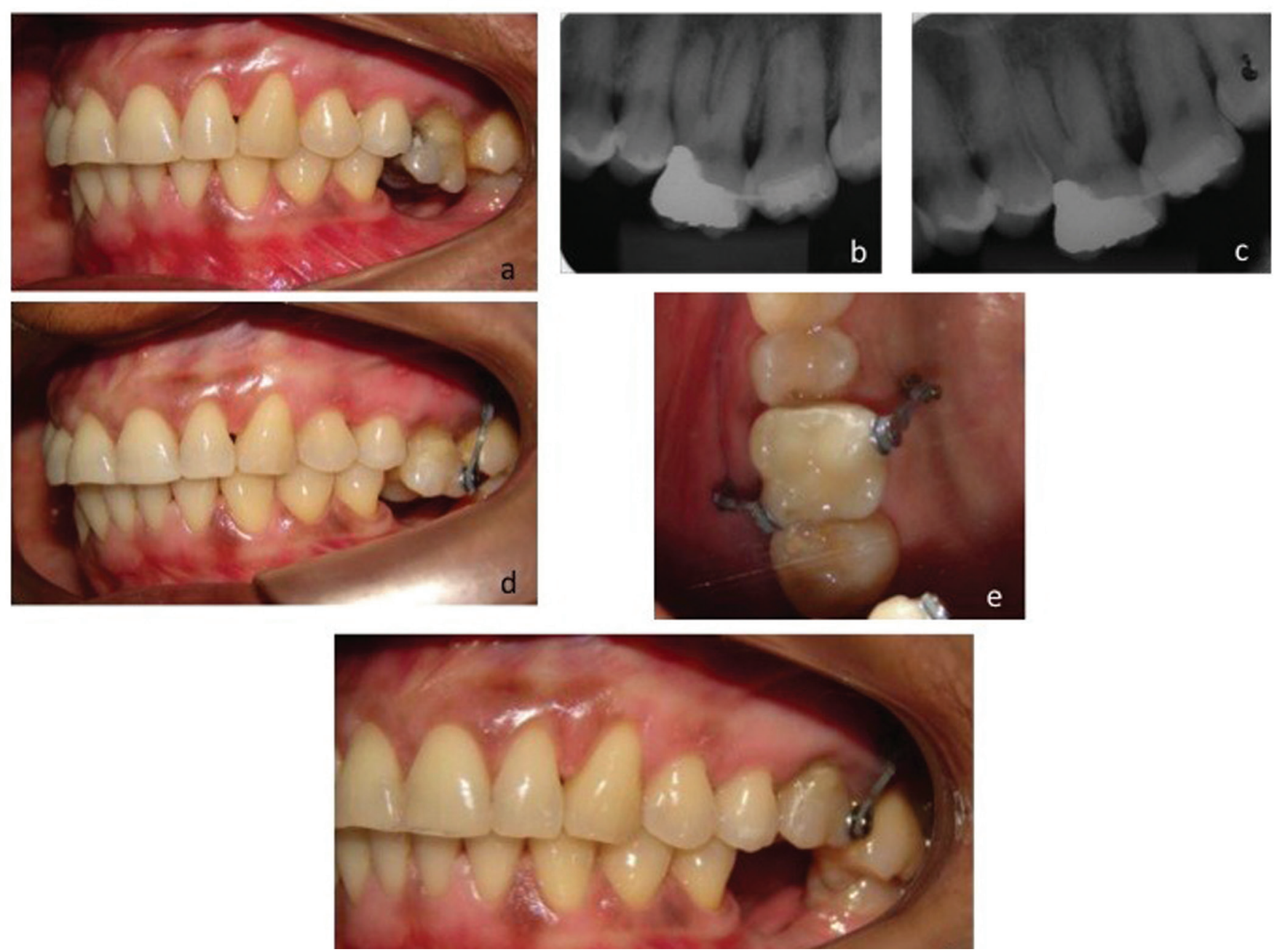

Figure 2. A) Initial image showing extrusion of tooth 26; B - C, Periapical radiographs before and after obtaining space between the roots; D - E, Mini-implants inserted in the vestibular region and palate. Chain elastics activated for intrusion of tooth 26 . Left side and occlusal views; F - after 6 months, conclusion of intrusion.

The intrusive forces from 150 to $200 \mathrm{~g}$ were obtained by means of chain elastics $2,8-9,16$, passing through the center of resistance of the maxillary molars, located in the direction towards the palatine root $9,13,15,17$.

For intrusion of the mandibular posterior teeth, in addition to the difficulty of inserting the miniimplants ${ }^{11,15}$, the mandibular bone presented a high degree of density, which made it difficult to obtain intrusive movement ${ }^{14}$. The mean force applied was 150 to $200 g^{1,2,4,15,18,20}$.

The intrusive tooth movement, especially that of the posterior teeth, was not aggressive to the periodontal structures; did not cause root resorption; did not change pulp flow, and therefore maintained the vitality of the intruded teeth ${ }^{15,19,21-22}$.

\section{CONCLUSION}

The mini-implants were demonstrated to be an efficient option for the intrusion of maxillary and mandibular teeth. Nevertheless, there is still a need for longitudinal studies that evaluate the mean quantity of intrusion; treatment time; velocity of intrusion; changes in coronal inclinations of the intruded molars, and their adverse effects.

\section{Collaborators}

CM TIAGO and L PREVIDENTE were responsible for the clinical part of the case and writing the article. PRA NOUER was responsible for digitization of the images, guidance of the work and writing the article. 

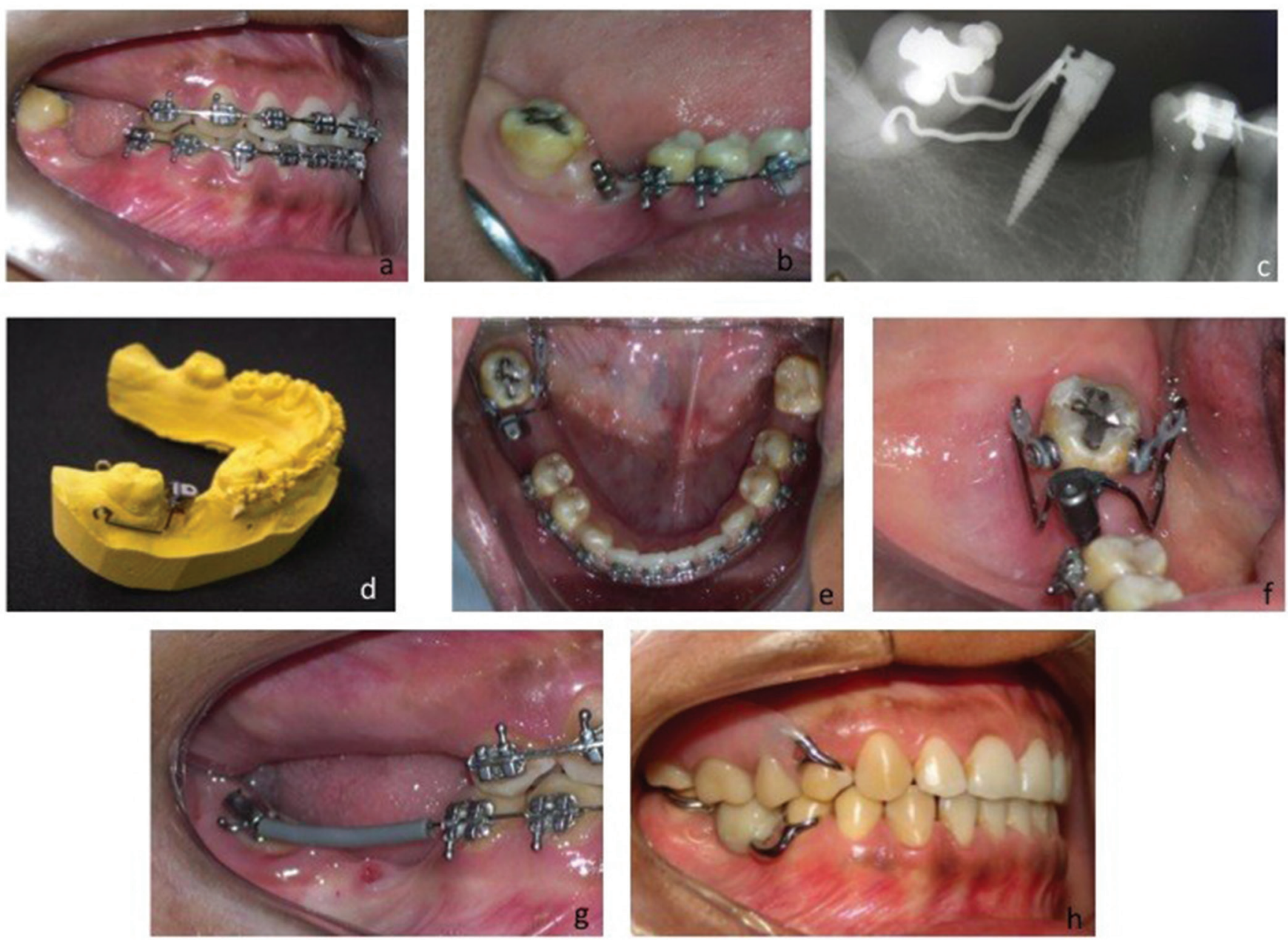

Figure 3. A - Absence of maxillary molars and extrusion of tooth 47; B - Insertion of orthodontic mini-implant (2.0 mm in diameter and $10 \mathrm{~mm}$ long); C - D, Radiographic image of orthodontic mini-implant and orthodontic abutment cemented. Transfer impression and construction of the force arms with steel .019" $\mathrm{x}$.025" archwire; $\mathrm{E}$ - F, occlusal view of the system for intrusion and verticalization; G - After intrusion, bonding the accessory for stabilization; $\mathrm{H}$ - Treatment concluded and oral rehabilitation performed.

\section{REFERENCES}

1. Janson M. A utilização rotineira dos mini-implantes na clínica ortodôntica. In: Ortodontia em adultos: e tratamento interdisciplinar. Maringá: Dental Press; 2008. p 359-405.

2. Yao CC, Wu CB, Wu HY, Kok SH, Chang HF, Chen YJ. Intrusion of the overerupted upper left first and second molars by miniimplants with partial-fixed orthodontic appliances: a case report. Angle Orthod. 2002;74(4):550-7.

3. Yang YM, Weng SE, Chen LL. [Preliminary clinical study on intrusion of overerupted molars with a removable appliance]. Shanghai Kou Qiang Yi Xue. 2007 Apr;16(2):161-7.

4. Xun C, Zeng X, Wang X. Microscrew anchorage in skeletal anterior open-bite treatment. Angle Orthod. 2007;77(1):4756.

5. Chun YSC, Woo YJE, Row J, Jung EJ. Maxillary molar intrusion with the molar intrusion arch. J Clin Orthod. 2000;34(2):90-3.

6. Laboissiere Junior M, Villela H, Bezerra F, Laboissiere EM, Diaz L. Ancoragem absoluta utilizando microparafusos ortodônticos: protocolo para aplicação clínica (trilogia parte II). Implant News. 2005;2(1):37-46.

7. Ritto AK, Kyung HM. Bracket head micro implant for orthodontic anchorage. Orthod Cyber J. 2004;1-17.

8. Arismendi JA, Campo AZM, Morales MB, Gonzáles FJC, Jaramillo PMV, Sánchez AU. Evaluación de la estabilidad de los miniimplantes como anclaje óseo para intrusión de molares superiores. Rev Fac Odontol Univ Antioq. 2007;19(1):60-74.

9. Araújo TM, Nascimento MHA, Franco FCM, Bittencourt MAV. Intrusão dentária utilizando mini-implantes. Rev Dental Press Ortodon Ortop Facial. 2008;13(5):36-48.

10. Araújo TM, Nascimento MHA, Bezerra F, Sobral MC. Ancoragem esquelética em Ortodontia com mini-implantes. Rev Dental Press Ortodon Ortop Facial. 2006;11(4):126-56. 
11. Sung JH, Kyung HM, Bae SM, Park HS, Kwon OW, Mc Namara Jr. A. microimplants in orthodontics. Korea: Dentos; 2006.

12. Yao CC, Lee JJ, Chen HY, Chang ZCJ, Chang HF, Chen YJ. Maxillary molar intrusion with fixed appliances and miniimplant anchorage studied in three dimensions. Angle Orthod. 2005;75(5):626-32.

13. Melo ACM, Zimmerman LL, Chiavini PCR, Belaver ES, Leal HA, Thomé G. O uso de mini-implantes como ancoragem ortodôntica - planejamento ortodôntico/ cirúrgico. Rev Clín Ortod Dental Press. 2007;5(6):21-8.

14. Kyung HM. Entrevista. Rev Dental Press Ortodon Ortop Facial. 2008;13(5):28-35.

15. Lee JS, Kim JK, Park YC, Vanarsdall Junior RL. Aplicações clínicas dos miniimplantes ortodônticos. São Paulo: Quintessence; 2009.

16. Kravitz ND, Kusnoto B, Tsay PT, Hohlt WF. Intrusion of overerupted upper first molar using two orthodontic miniscrews: a case report. Angle Orthod. 2007;77(5):915-22.

17. Kravitz ND, Kusnoto B, Tsay P, Hohlt WF. The use of temporary anchorage devices for molar intrusion. J Am Dent Assoc. 2007;138(1):56-64. doi: 10.14219/jada.archive.2007.0021

18. Kravitz ND, Kusnoto B. Risk and complications of orthodontic miniscrews. Am J Orthod Dentofacial Orthop. 2007;131(41):43-51. doi: 10.1016/j.ajodo.2006.04.027
19. Carrilo R, Buschang PH, Opperman LA, Franco PF, Rossouw PE. Segmental intrusion with mini-screw implant anchorage: A radiographic evaluation. Am J Orthod Dentofacial Orthop. 2007;132:576e1-576e6. doi: 10.1016/j.ajodo.2007.05.009

20. Sugawara J, Baik UB, Umemorim M, Takahashi I, Nagasaka $\mathrm{H}$, Kawamura $\mathrm{H}$, et al. Treatment and posttreatment dentoalveolar changes following intrusion of mandibular molars with application of a skeletal anchorage system (SAS) for open bite correction. Int J Adult Orthodon Orthognath Surg. 2002;17(4):243-53.

21. Kanzaki R, Daimaruya T, Takahashi I, Mitani H, Sugawara J. Remodeling of alveolar bone crest after molar intrusion with skeletal anchorage system in dogs. Am J Orthod Dentofacial Orthop. 2007;131(3):343-51. doi: 10.1016/j. ajodo.2006.04.025

22. Konno $Y$, Daimaruya T, Likubo M, Kanzaki R, Takahashi I, Sugawara J, et al. Morphologic and hemodynamic analysis of dental pulp in dogs after molar intrusion with the skeletal anchorage system. Am J Orthod Dentofacial Orthop. 2007;132(2):199-207.
Received on: $17 / 5 / 2016$

Final version resubmitted on: 9/6/2016

Approved on: 2/8/2016 